Skulle man få lyst til at supplere den med andre forskeres bud på en udlægning af Darwins værker, så kan man jo altid gå på jagt i nærværende tidsskrift, da Slagmark i foråret 2009 udgav et temanummer (nr. 54) om darwinisme.

MIKKEL THORUP

\section{Traktat om de tre bedragere}

Anonym: Traktat om de tre bedragere, oversat af Claus Bratt Østergaard, forord ved Frederik Stjernfelt, Informations Forlag, 2010, 176 sider, 199,- kr.

Det er et ofte hørt argument fra religiøse for religion, at der altid har været folk, der troede på noget guddommeligt. At tro altså er noget mennesket iboende. Argumentationen kan dog vendes om, idet der på samme tid også altid har eksisteret skeptikere, agnostikere, fritænkere og ateister. De har bare sjældnere efterladt sig skriftlige, rituelle, ikoniske, institutionelle eller arkitektoniske vidnesbyrd, ikke mindst fordi det $\mathrm{i}$ sandhed er en transhistorisk sandhed, at den religionskritiske eller religionsløse er blevet forfulgt af den religiøse.

Det er også vilkåret for denne anonymt udgive tekst, der tilsyneladende er startet som et rygte (og som bagvaskelse af dem, religiøse og politiske magter har villet delegitimere) for på et tidspunkt at manifestere sig som det, teksten blev beskyldt for at være, før den endnu eksisterede som faktisk tekst, nemlig som en rasende anklage imod den religiøse undertrykkelse. Traktaten er ikke et angreb på religion som sådan. Teksten selv synes at have et panteistisk grundsyn. Men den er et frontalangreb på religionsstiftere og på alle, som bruger religion til at undertrykke andre med. Den er ikke sofistikeret, men dog belæst.

Bogens forord af Frederik Stjernfelt opruller på fornem vis tekstens mysteriøse ophav, de mange rygter om den, diskussionerne om dens forfatter(e) samt den publicerings- og receptionshistoriske vigtige pointe om forholdene for publicering af den slags litteratur samt faren ved at læse, eje og forholde sig til den. Det er et vigtigt forhold ved megen af den litteratur, vi som idéhistorikere arbejder med, at de kun kunne udgives anonymt, at der skulle bedrag, mod og smugleri til for at udbrede dem, og at teksterne ofte blev kopieret, ændret og forfalsket af andre, således at selve forestillingen om forfatteren og budskabet i deres strenge forstand bliver anstrengt eller decideret meningsløs. Her har vi en tekst, hvis afsender eller snarere 
afsendere, vi ikke kender; en tekst, der formodentlig er et sammenkog af en mængde forskellige arbejder på forskellige tidspunkter; en tekst som alle har kunnet skære fra og lægge til, indtil den fik den form i 1719, der nu udgives på dansk.

Stjernfelt og en række af dens avisanmeldere har set en aktuel og presserende relevans $i$ dens udgivelse, der ikke er baseret først og fremmest på dens indhold, men på at religiøse fanatikere igen undertrykker fornuften og det frie ord. Hvis det var bogens relevans, da havde den ingen anden end at være et eksempel på en tekst, der kun kunne udgives anonymt, men heldigvis har den andre og mere interessante budskaber. Først og fremmest som vidnesbyrd om religionskritik i den tidlige oplysning eller i det, som oplysningshistorikeren Jonathan Israel kalder for den radikale oplysning, der var inspireret ikke mindst af Baruch de Spinoza og hans religionskritik. Den anonyme traktat angives da også (fejlagtigt) at være om "M. Benoit Spinosas Liv og Ånd”. Bogens udgivelse flugter godt med den forøgede opmærksomhed i disse år på netop den radikale oplysning, Spinoza og på den såkaldt klandestine litteratur, der mestendels var religions- og monarkikritisk. Der er stadig megen litteratur og meget historisk såvel som idéhistorisk arbejde at gøre med at fremdrage denne litteratur, der har eksisteret sideløbende med den kanoniserede og ofte langt mere moderate litteratur, som forskningen ofte nøjes med, når størrelser som 'oplysningen' $\mathrm{og}$ 'moderniteten' behandles.

Som idéhistorisk dokumentation af den radikale oplysnings religionskritik er teksten essentiel og vigtig (Jens Glebe Møllers Vi fornagter Gud og foragter ourigheden. Studier i den tidlige oplysning, Museum Tusculanum, 2004, kan med stort udbytte læses sideløbende). Vi får i traktaten en slags religionssociologisk fremlæggelse af, hvordan religioner er blevet skabt, og hvorfor de bliver troet. Bogen sætter sig for at afsløre tre bedragere, de tre grundlæggere af de store monoteistiske religioner: Moses, Jesus og Muhammed. Teksten søger at vise, hvorledes religionsgrundlæggerne har benyttet sig af bedrag, trylleri og militærmagt til at opkaste sig til profeter.

En stor del af tekstens energi kommer fra den nådesløse fremhævning af interne selvmodsigelser i dogmerne og særligt det alt andet end hellige ophav til samme. Man kan vel sige, at teksten opskriver den sunde skepsis ethvert rettænkende menneske må have over for sådan noget som jomfrufødsler, folk der hører guds stemme, brændende tornebuske og deslige. 
Måske disse fænomener har en mere rationel forklaring end den guddommelige, nemlig som bedrag og manipulation fra dem, der bruger referencen til det hinsides til at vinde jordiske gevinster: "Religionens grundlæggere sørgede omhyggeligt for, at folks uvidenhed var det faste udgangspunkt for deres svindel, og de glemte ikke at fastholde dem i denne tilstand."

Disse bedrag lykkes kun, fordi fornuften formørkes af de religiøse bedrageres skabelse af frygt. Befolkningen er blevet lært ikke at stille spørgsmål, at tro på absurditeter, selvmodsigelser og "vamle ideer om Gud". Teksten har fem afdelinger: en indledning, der foregiver at være en advarsel imod skriftet; kapitel 1-4 handler om, hvad gud og religion er; kapitel 5-11 handler om Moses, Numa, Muhammed og Jesus (hvor sidstnævnte får 4 kapitler om hans politik, moral og guddommelighed, de andre kun ét); fjerde del, kap. 12-17, er hentet fra andre tekster, nemlig fra Pierre Charron og Gabriel Naudé (og er bogens mindst interessante); og endelig sidste del, kap. 18-21, der handler om ånder og sjælen: "Men hvorhen fører dette ræsonnement? Det leder os ubønhørligt til, at vi må erkende, at Gud, Djævelen, Paradis, Helvede og Sjælen ikke er, som de fremstilles i religionen; endvidere, at teologerne, dvs. dem der kolporterer æeventyr som åbenbarede sandheder, bortset fra nogle enkelte ignoranter, er nogle uredelige mennesker, der på det nederdrægtigste misbruger folks godtroenhed for at få dem til at tro, hvad de ønsker [...] Verden har for længe ladet sig fortrylle af denne meningsløse maksime: at sandheden ikke var noget for folket, og at folket ikke var i stand til at fatte den."

Teksten er klassisk oplysningsfilosofisk i sin overbevisning om, at afsløring af tingenes sande tilstand vil føre til en omvending i folks forestillingsverden. Frygten "for usynlige magter er kimen til religionerne." Uden denne frygt og disse bedrag og undertrykkelser vil fornuften af sig selv indse sandheden: "Hvis folk blot kunne se, hvad det er for en afgrund, som denne uvidenhed styrter dem ud i, ville de utvivlsomt kaste det åg af sig, som disse kræmmersjæle har lagt på deres skuldre alene for at varetage egne interesser. For at se dette, skal man blot gøre brug af sin fornuft." 